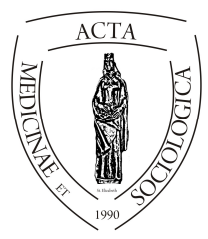

Acta Medicinae et

Sociologica (2018)

\title{
A nyíregyházi lakosság vallásossága és annak szubjektív egészségi állapottal való összefüggése
}

\author{
Hüse Lajos ${ }^{1}$ \\ ${ }^{1}$ főiskolai docens, Debreceni Egyetem Egészségügyi Kar. 4400 Nyíregyháza, Sóstói u. 2-4.
}

\begin{tabular}{|c|c|}
\hline INFO & ABSTRACT \\
\hline $\begin{array}{l}\text { Hüse Lajos } \\
\text { huse.lajos@foh.unideb.hu }\end{array}$ & \multirow[b]{2}{*}{$\begin{array}{l}\text { Religiosity of the inhabitants of Nyíregyháza and its } \\
\text { correlation with the subjective health status: The } \\
\text { Centrality of Religiosity Scale (CRS; Huber and Huber, } \\
\text { 2012), which is used on the latest wave of life quality } \\
\text { research in Nyiregyháza, describes the inhabitatnts' religious } \\
\text { attitude. A quarter of the population is characterized by } \\
\text { formal religious participation, half of the sample pray. The } \\
\text { smaller part of the population is characterized by the } \\
\text { following of the ecclesiastical way, more of them practise in } \\
\text { their own way. Women, the elderly and those, who } \\
\text { experienced life burdens are more likely to practice a } \\
\text { religious activity. Religion closely correlated with subjective } \\
\text { health: the worse health was described, the more intense of } \\
\text { religiosity was detected in all five aspects. }\end{array}$} \\
\hline $\begin{array}{l}\text { Keywords } \\
\text { religiosity } \\
\text { subjective health status }\end{array}$ & \\
\hline $\begin{array}{l}\text { Kulcsszavak } \\
\text { vallásosság } \\
\text { szubjektív egészség }\end{array}$ & $\begin{array}{l}\text { Absztrakt: A Nyíregyháza Életminősége kutatás legújabb } \\
\text { hullámában szereplő The Centrality of Religiosity Scale } \\
\text { (CRS; Huber és Huber, 2012) alapján leírható a nyíregyházi } \\
\text { lakosság vallásossághoz való viszonyulása. A lakosság ne- } \\
\text { gyedére jellemző a formális vallásos részvétel, felére az } \\
\text { imádkozás. A lakosság kisebb részére jellemzó az egyházias } \\
\text { út követése, többen a maguk módján vallásosak. A nők, az } \\
\text { idősebbek és a nehéz élethelyezett átéltek jellemzőbben } \\
\text { gyakorolják valamely vallásos tevékenységet. A vallásosság } \\
\text { szoros összefüggést mutatott a szubjektív egészségi állapot- } \\
\text { tal: az egészségüket rosszabbnak érzékelők jellemezték } \\
\text { magukat intenzívebb vallásossággal mind az öt szempont } \\
\text { szerint. }\end{array}$ \\
\hline
\end{tabular}

Ez a tanulmány a Nyíregyháza város életminősége - Háztartáspanel kutatás Egészségi állapot felmérése keretében készült. 


\section{A vallásosság és a spiritualitás szerepe az életminőség alakításában}

A vallás és a spiritualitás életminőségben játszott szerepét vizsgálva érdemes visszanyúlni a vallásszociológia kezdetét jelentő gondolatokig, miszerint a vallás legfontosabb szerepe a rituálék biztosítása. A rituálék nyújtják és erősítik meg a társadalom tagjai számára a közösségi értékeket, melyek elfogadásán alapszik az együttmüködés és a társadalmi integráció (Durkheim 2003). Egy másik szempontot ragad meg Luckmann, amikor kijelenti, hogy a vallások a legnehezebben megválaszolható, egzisztenciális kérdésekre keresnek és adnak válaszokat. Ezáltal a vallási világkép támaszt nyújt az egyénnek ahhoz, hogy a világban tájékozódni tudjon (Luckmann 1963, 1991 - hivatkozza Bognár 2008). A jelenleg érvényes felfogás szerint a vallás e két funkciója, azaz a közösségek összetartása és az egyén eligazitása a bonyolult világban, egybefonódva adja a személyes jól-lét alapjait, nem csupán azokban a korszakokban, amikor a vallásos világkép egyeduralkodó volt, de a tudományos racionalitás térnyerését követően is. Igaz, ezt követően az említett funkciók felett a vallás elveszti kizárólagos kontrollját (pl. a társadalmi kohéziót a nemzettudat, a világban való eligazodást a természet- és társadalomtudomány magyarázatai is szolgáltathatják), illetve a szekularizáció nyomán kialakuló, megerősödő intézmények jogot formálnak az egyház(ak) korábban kizárólagos szerepeire. Emellett megjelenik a spiritualitás, mint a vallásosságot részben átfedő fogalom, amely sokaknál betöltheti a fenti funkciókat.

A vallás és a spiritualitás az adaptációt szolgáló erős karakterjegyként az egyéni megküzdési (coping) stratégiák fontos eleme (Pikó, 2005; Steen, Kachorek, és Peterson, 2003). A transzcendenciához való viszony, az élet értelmébe vetett hit, annak elfogadása, hogy személyes életünknek (és általában véve az emberi életnek) célja van, elősegíti a mentális egészség megőrzését, a testi és lelki egészség egységét, az életeseményekhez való alkalmazkodást, az életproblémák kezelését, a hétköznapok történéseihez, önmagunkhoz és másokhoz füződő pozitív hozzáállást (Miller és Thoresen, 2003, Pikó, Kovács és Kriston, 2011).

A társas támasz életminőségre gyakorolt hatásának kérdésében a vallásosság szerepére fókuszálva érdemes megvizsgálni, hogy a pozitív hatást egyszerüen a közösség által nyújtott társas támogatás eredményezi-e, vagy hozzájárul ehhez a vallás nyújtotta speciális értékek hatása is. Az egyházi tagoktól kapott társas támogatás egészségre gyakorolt hosszú távú hatásának vizsgálta során kiderült, hogy a hívők társadalmi státusza az egyházon belül is leképződik, azaz a tagok elsősorban a hozzájuk hasonlóaktól kapnak támogatást. A papok által nyújtott szociális támasz viszont kevéssé bizonyult jelentősnek (Krause és Ellison 2002 - idézi Barna 2007).

Marmot (1976, 1989 - idézi Kopp, Székely és Skrabski 2004) vizsgálatai szerint azok az Egyesült Államokban élő japán férfiak, akik nagyon erősek nemzeti identitásukban és kifejezik a közösséghez tartozást, tartják a japán szokásokat, ötvenéves kor alatt ötször, ötvenéves kor felett pedig háromszor ritkábban kaptak szívinfarktust, mint azok a japánok, akik modernizálódott, amerikanizálódott életmódot folytatnak. A közösséggel való azonosulásnak tehát biológiailag kimutatható egészség- 
védő hatása van. Ezek a vizsgálatok arra engednek következtetni, hogy a gyülekezeti-egyházi társas támogatás lényegében nem több, mint bármely hasonlóan szoros közösségben megélhető támogatás - ugyanakkor a hasonló, de nem-vallásos egészségvédő mechanizmusok megléte nem cáfolja a vallásos közösségek egészségvédő hatásának feltárt eredményeit.

Hasonlóan összetett kérdés a vallás nyújtotta koherens világkép és életcél pozitív hatásának vizsgálata. Számos vizsgálat kimutatta, hogy az életminőségre a vallás ilyen módon is pozitívan hat - de úgy tünik ugyanezt a koherens világképet, illetve a kihívást jelentő életcélokat a valláson kívül más rendszer is biztosíthatja - ezek közül példaként ragadom ki Frankl (1996) logoterápiáját és egzisztenciaanalizisét, valamint Csíkszentmihályi (1996) flow-elméletét.

Livingston (2002) vizsgálata szerint függetlenül attól, hogy valaki vallásos-e, vagy sem, kevésbé boldogtalanok azok a személyek, akik koherens, szisztematikus világképpel rendelkeznek. Livingston megállapította, hogy a teljes ateizmustól az erős hitig terjedő skálán a két szélső csoport a legkevésbé boldogtalan. A stabil ateisták és az erősen vallásosok egyaránt határozott, biztos elképzeléseken nyugvó, egységes világképpel rendelkeznek, amely kielégíti a világban való eligazodás igényét.

A három Hungarostudy felmérés $(1988,1995,2002)$ a 18 évesnél idősebb magyar népességet életkor, nem és terület szerint reprezentálta (Kopp 2003; Kopp és Skrabski 2003; Skrabski és mtsai. 2004). A vizsgálatsorozatban az egészségi állapot és az életmód szociális és pszichológiai összefüggéseit elemezték, különösképpen azt, hogy milyen tényezők tekinthetők leginkább egészségvédőnek. A 1995-ös és 2002-es hullámban a vallásosságra vonatkozó kérdések is szerepeltek, így azok elemzésére is sor került (Rózsa és mtsai. 2003; Kopp 2003). Ezek eredményei szerint a vallásgyakorlás és a vallás fontosságának megítélése leginkább az életkorral, nemmel, az anyagi helyzettel és az iskolázottsággal állt kapcsolatban, ezért a vallás és az egészség összefüggéseinek elemzésénél a szerzők minden esetben korrigálták az adatokat, elkerülendő a téves következtetéseket. A kutatás tanulsága szerint a vallásgyakorlás minden vizsgált változó esetében jobb testi és lelki egészséggel jár együtt. A vallásgyakorlók az országos átlaghoz képest 43\%-kal kevesebb cigarettát szívnak el naponta, és $42 \%$-kal kevesebb napig voltak betegek a vizsgálatot megelöző évben, ezzel párhuzamosan a munkaképességük jelentősen jobb. Szignifikánsan magasabb értéket értek el jóllétet reprezentáló skálán, kevésbé depressziósak, kevésbé ellenségesek, ugyanakkor kooperatívabbak, kevésbé jellemzik őket káros érzelmi megbirkózási módok, jellemzőbb rájuk a problémamegoldó konfliktusmegoldás, és szignifikánsan több társas támogatásról számoltak be szüleik és munkatársaik részéröl (Kopp, Székely és Skrabski 2004).

\section{Anyag és módszer}

A „Nyíregyháza életminősége 2018” panelkutatás 5. hullámának teljes adatfelvétele 2017. októberétől 2018 május közepéig zajlott, az utóbbi években jellemző magas válaszmegtagadási arány (az eredeti címek 45 százaléka nem vállalta a részvételt) 
mellett. A Közigazgatási és Elektronikus Közszolgáltatások Központi Hivatala által szolgáltatott címek mellé így saját mintavételi módszerrel további kiegészítô címeket kellett alkalmazni, így összesen 540 háztartás került be a mintába, melynek jellemzőiről lásd Huszti Éva és munkatársai (2018) tanulmányát.

Az előző négy hullámtól eltérően (Fábián és mtsai, 2018) az új vizsgálatban a lakosság vallásosságának mértéke is fókuszba került. Az erre irányuló blokkban a vallásosság skála (The Centrality of Religiosity Scale, CRS - Huber és Huber, 2012) egyszerüsített verziójának alkalmazásával mértük a vallásosság jellegét és mértékét, amely mind az általános, mint az egészségi állapot felmérésére irányuló kérdőivben helyet kapott, de jelen tanulmányban a kiadvány tematikájának megfelelően kizárólag az általános adatbázisra fókuszálunk. Az öt itemből álló skála alkalmas arra, hogy külön kezeljük a vallásos részvétel (religious attendance) és a vallásos hit (religious belief) kérdését, amelyek számos vizsgálatban eltérő hatást gyakorolnak az egyének viselkedésére (vö. Glaeser és Sacerdote 2002). A részvétel és a hit különjárárásáról érdekes eredmény született a „Nyíregy-háza életminősége 2018” panelkutatás adatbázisán is, ahol Takács és Fábián (2018) a multihalmaz elmélet keretrendszerében bizonyítja a vallásos hit itemeinek szorosabb korrelációját, illetve a vallásos részvétel viszonylagos elkülönülését a többi itemtől.

Jelen vizsgálatban megkíséreltük továbbá a CRS itemeit megfeleltetni a Glock és Stark (1965 - hivatkozza Földvári és Rosta 1998) által megfogalmazott dimenzionális megközelítésnek is. Ezek a dimenziók különböző, egymástól jól elkülöníthető területet határolnak le: a hit (ideológiai dimenzió), vallásgyakorlat (rituális dimenzió), vallási érzés, élmény (élmény és tapasztalat dimenziója), vallási ismeretek (intellektuális dimenzió), és a mindennapi élet vallásossága (következmény dimenzió). A modell alapkoncepciója, hogy a modern társadalomban az egyes dimenziók függetlenednek egymástól, és az egyéni preferenciáktól függ, hogy ki melyik dimenzióban milyen attitüdöt mutat. A CRS itemeit az 1. táblázatban feltüntetett módon feletettük meg a vallásosság dimenziónak.

\begin{tabular}{|l|c|}
\hline \multicolumn{1}{|c|}{$\begin{array}{c}\text { A vallásosság dimenziói Glock és Stark } \\
\text { (1965) szerint }\end{array}$} & $\begin{array}{c}\text { A CRS itemei } \\
\text { (Huber és Huber 2012) }\end{array}$ \\
\hline hit (ideológiai dimenzió) & Hiszem, hogy Isten létezik \\
\hline vallásgyakorlat (rituális dimenzió) & $\begin{array}{c}\text { Templomba vagy gyülekezetbe járok Imád- } \\
\text { kozom }\end{array}$ \\
\hline $\begin{array}{l}\text { vallási érzés, élmény (élmény és tapasztalat } \\
\text { dimenziója) }\end{array}$ & $\begin{array}{c}\text { Megtapasztaltam, hogy Isten része a szemé- } \\
\text { lyes életemnek } \\
\text { Gyakran gondolkodom vallásos dolgokról }\end{array}$ \\
\hline vallási ismeretek (intellektuális dimenzió) & - \\
\hline $\begin{array}{l}\text { mindennapi élet vallásossága (következmény } \\
\text { dimenzió) }\end{array}$ & - \\
\hline
\end{tabular}

1. táblázat. A CRS illeszkedése a vallásosság dimenzióihoz.

A vallásosság életminőségre gyakorolt hatását a szubjektív egészségi állapot vonatkozásában vizsgáljuk. Az adatok értelmezése során, amennyiben a négyfokú skálát egyszerűsítve magyarázzuk, a „nagyon jellemző” és „kicsit jellemző” válaszokat 
jellemzőnek, az „inkább nem jellemző” és „egyáltalán nem jellemző” válaszokat pedig nem jellemzőnek tekintjük.

\section{Eredmények}

A nyíregyházi lakosság életminőségének vizsgálatára irányuló kutatás-sorozat ötödik hullámában kapott eredményeken is jól látható, hogy a vallásosság különféle aspektusai, dimenziói napjainkban elválnak egymástól. A nyíregyházi válaszadók egyéni preferenciákban előnyben részesítik az Istenbe vetetett hitet, amely meglétéről a megkérdezettek 61,0 százaléka számolt be. Figyelembe véve a CRS másik négy szempontját, amelyek részben mentális és lelki tartalmakról, valamint vallásos gyakorlatokról szólnak, kijelenthetjük, hogy az önbevalláson alapuló istenhit sokak esetében tartalmatlan - létezik, de jobbára nem befolyásolja még azok viselkedését sem, akik a hitükről, mint rájuk nagyon jellemző dologról számoltak be (35,2 \%). Az imádkozás gyakorlata már csak a megkérdezettek 47,4 százalékára, a vallásos gondolatok 42,5 százalékára jellemző, míg azok aránya, akik megtapasztalták Isten személyes jelenlétét az életükben, már csak 37,8 százalék, azaz szinte a fele azoknak, akik hisznek Istenben. Ehhez képest a formális vallásgyakorlók aránya méginkább eltörpül, hiszen a megkérdezettek 26,9 százaléka jár templombagyülekezetbe, de azok, akikre ez valószínüleg kellő rendszereséggel jellemző, mindössze a minta egytizedét tették ki (2. táblázat). A Tomka Miklós (1996) által alkalmazott kategóriát alkalmazva tehát azt mondhatjuk, hogy az istenhívők jelentős része a maga módján vallásos, amely szociológiai fogalommal jól leírható az a csoport, amely az egyházaktól - és a vallásos csoport támogatásától - távol éli meg hitét, amely elég széles spektrumon mozoghat, a „biztos-ami-biztos” babonaságtól a mélyen megélt, az életminőség szempontjából a formalizált vallásossággal egyenértékủ spiritualitásig.

\begin{tabular}{|l|c|c|c|c|}
\hline & nagyon & kicsit & inkább nem & $\begin{array}{c}\text { egyáltalán } \\
\text { nem }\end{array}$ \\
\hline $\begin{array}{l}\text { Hiszem, hogy Isten létezik } \\
\text { (N: 415) }\end{array}$ & 35,2 & 25,8 & 16,2 & 22,8 \\
\hline $\begin{array}{l}\text { Templomba vagy gyülekezetbe } \\
\text { járok (N: 455) }\end{array}$ & 10,0 & 16,9 & 26,7 & 46,3 \\
\hline Imádkozom (N: 417) & 20,3 & 27,1 & 16,3 & 36,3 \\
\hline $\begin{array}{l}\text { Megtapasztaltam, hogy Isten } \\
\text { része a személyes életemnek (N: } \\
\text { 413) }\end{array}$ & 16,2 & 21,6 & 21,6 & 40,6 \\
\hline $\begin{array}{l}\text { Gyakran gondolkodom vallásos } \\
\text { dolgokról (N: 455) }\end{array}$ & 15,3 & 27,2 & 26,7 & 30,9 \\
\hline
\end{tabular}

2. táblázat. A CRS egyes itemeire adott válaszok megoszlása az általános mintában (\%). 
A vallásosság dimenzionális megközelítésében a CRS itemeit három dimenzióba soroltuk, bár vitatható például, hogy az ,imádkozom” miért a rituális és miért nem a következmény dimezióba került. Azon dimenziók esetén, amelyek két CRS-itemet foglalnak magukba, az itemekre adott válaszok átlagával számoltunk. Ez esetben a „kicsit jellemző” értéke 2,5-3,0; a „nagyon jellemző” értéke pedig 3,5-4,0 volt. Eszerint is észlelhetö a „tartalmas hit” és a „tartalom nélküli istenhit” közötti különbség, amely különösen azok körében mutat éles eltérést, akikre az egyes dimenzió az önjellemzésük alapján nagyon jellemző (3. táblázat).

\begin{tabular}{|l|c|c|c|c|}
\hline & \multicolumn{4}{|c|}{ Mennyire jellemzö? } \\
& nagyon & kicsit & inkább nem & $\begin{array}{c}\text { egyáltalán } \\
\text { nem }\end{array}$ \\
\hline hit (ideológiai dimenzió) (N: 415) & 35,2 & 25,8 & 16,2 & 22,8 \\
\hline $\begin{array}{l}\text { vallásgyakorlat (rituális dimen- } \\
\text { zió) (N: 415) }\end{array}$ & 15,8 & 26,4 & 24,2 & 33,6 \\
\hline $\begin{array}{l}\text { vallási érzés, élmény (élmény és } \\
\text { tapasztalat dimenziója) (N: 413) }\end{array}$ & 17,8 & 25,5 & 27,7 & 29,0 \\
\hline
\end{tabular}

3. táblázat. A vallásosság három dimenziójának megoszlása az általános mintában (\%).

A vallásosság megoszlásában erőteljes különbségek tárhatók fel a nemek viszonylatában. Azon túl, hogy a férfiak vallásossága minden szempont szerint elmarad a nők vallásossághától, a 4. táblázat adatai arra is rámutatnak, hogy míg ez a különbség az istenhit esetében nem számottevő, a formális vallási részvétel a nőkre mintegy másfélszer gyakrabban jellemző, a többi szempontot vizsgálva pedig közel kétszeres arányban jellemző a férfiakhoz képest.

\begin{tabular}{|l|c|c|c|c|}
\hline \multirow{2}{*}{} & \multicolumn{2}{|c|}{ férfi } & \multicolumn{2}{c|}{ nő } \\
\cline { 2 - 5 } & jellemző & $\begin{array}{c}\text { nem } \\
\text { jellemzö }\end{array}$ & jellemzö & $\begin{array}{c}\text { nem } \\
\text { jellemző }\end{array}$ \\
\hline Hiszem, hogy Isten létezik & 52,2 & 47,8 & 68,0 & 32,0 \\
\hline $\begin{array}{l}\text { Templomba vagy gyülekezet- } \\
\text { be járok }\end{array}$ & 19,8 & 80,2 & 32,4 & 67,6 \\
\hline Imádkozom & 33,0 & 67,0 & 59,2 & 40,8 \\
\hline $\begin{array}{l}\text { Megtapasztaltam, hogy Isten } \\
\text { része a személyes életemnek }\end{array}$ & 26,5 & 73,5 & 46,7 & 53,3 \\
\hline $\begin{array}{l}\text { Gyakran gondolkodom vallá- } \\
\text { sos dolgokról }\end{array}$ & 28,0 & 72,0 & 53,7 & 46,3 \\
\hline
\end{tabular}

4. táblázat. A vallásosság megoszlása nemek szerint (\%).

A vallásosság családi állapot szerinti vizsgálata is érdekes eredményre vezetett. Egyfelől leképeződik benne az életkori jellegzetesség, miszerint a fiatalok (nőtlen és hajadon) lényegesen kevésbé vallásosak, mint az idősek (özvegy), másfelől a nehéz élethelyezben élők - vagy korábban nehézségeket átélők - jellemzően magasabb arányban fordulnak a transzcendencia felé a vallásosság különböző formáival (elvált, özvegy). Ezek, mondhatni, megfelelnek a várakozásoknak. Emellett érdemes 
kiemelni, hogy a házasok rendre magasabb arányban vallották magukat ilyen, vagy olyan módon vallásosnak, mint az élettárssal élők - vélhetően sokak számára éppen a vallásos hozzáállás lehetett az egyik alapja a házasságkötésnek is (5. táblázat).

\begin{tabular}{|c|c|c|c|c|c|}
\hline & 总 & 胥 & 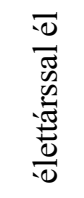 & $\frac{ \pm}{\frac{\pi}{\pi}}$ & $\begin{array}{l}\overrightarrow{0} \\
\overbrace{0}^{\infty}\end{array}$ \\
\hline Hiszem, hogy Isten létezik & 46,4 & 64,9 & 59,2 & 68,0 & 75,7 \\
\hline $\begin{array}{l}\text { Templomba vagy gyülekezetbe } \\
\text { járok }\end{array}$ & 14,0 & 34,1 & 16,9 & 17,7 & 38,7 \\
\hline Imádkozom & 33,6 & 53,0 & 36,0 & 54,1 & 64,9 \\
\hline $\begin{array}{l}\text { Megtapasztaltam, hogy Isten része } \\
\text { a személyes életemnek }\end{array}$ & 27,0 & 40,5 & 26,0 & 34,8 & 63,9 \\
\hline $\begin{array}{l}\text { Gyakran gondolkodom vallásos } \\
\text { dolgokról }\end{array}$ & 27,0 & 45,2 & 32,2 & 50,0 & 64,4 \\
\hline
\end{tabular}

5. táblázat. A vallásosság aránya családi állapot szerint (,jellemző”, \%).

A vallásosság és a szubjektív egészségi állapot összefüggéseit vizsgálva a CRS mellé a vélt egészség mutató (self perceived health) mérésére a WHO ajánlásának megfelelö ötfokozatú skálát (Tokaji, Faragó és Boros, 2011) vontuk be. A nyíregyházi életminőségvizsgálat általános mintáján nem a várt irányú összefüggést kaptuk, miszerint annál jobb szubjektív egészségi állapot rögzíthető, minél inkább vallásos a megkérdezett, hanem ennek pont a fordítottját kaptuk, amely ráadásul még a vallásos hit és a vallásos részvétel síkjain sem mutatott más képet (6. táblázat). A szubjektív egészségi állapotban a vallásosság fokozatainak fényében mérhető különbség minden esetben szignifikáns volt. Az eredményeket az életkori összefüggések magyarázhatják, ugyanis mintánkban minél idősebb volt valaki, annál nagyobb eséllyel hitt Istenben: a 19-39 évesek azonos arányban hittek, illetve nem hittek Istenben, a 40-59 évesek csoportjában a hívők másfélszer többen, a 60-79 évesek csoportjában pedig háromszor többen voltak, mint a nem hívők. A vallásos részvétel esetében bár a minta egészére kevésbé jellemzö, mint a vallásosság többi mutatója, ezért azok, akik nem járnak templomba/gyülekezetbe, mindig többen vannak - az életkor előrehaladtával ugyancsak megnőt a formális vallásgyakorlók aránya: a 19-39 évesek között a vallásukat formálisan nem gyakorlók közel hatszor, a 40-59 évesek között két és félszer, a 60-79 évesek között már csak 1,3-szor vannak többen, mint a templomba vagy gyülekezetbe járók. Emellett egy fordított logikájú magyarázat is elképzelhető: azok, akik (nagyon) rossznak érzékelik egészségi állapotukat, nagyobb valószínúséggel fordulnak a vallásosság felé - ez azonban inkább babonás segítségvárás, vagy a „személyes hit” jellegét ölti magára, melyet jól mutat, hogy ez a csoport a formális részvételben nem emelkedik ki. 


\begin{tabular}{|c|c|c|c|}
\hline \multirow{2}{*}{ szubjektív eü áll. } & \multicolumn{3}{|c|}{ Hiszem, hogy Isten létezik } \\
\hline & nem jellemzö & jellemzö & összesen \\
\hline (nagyon) jó & 49 & 51 & 100 \\
\hline elfogadható & 27 & 73 & 100 \\
\hline \multirow[t]{3}{*}{ (nagyon) rossz } & 27 & 73 & 100 \\
\hline & \multicolumn{3}{|c|}{ Templomba vagy gyülekezetbe járok } \\
\hline & nem jellemző & jellemző & összesen \\
\hline (nagyon) jó & 78 & 22 & 100 \\
\hline elfogadható & 65 & 35 & 100 \\
\hline \multirow[t]{3}{*}{ (nagyon) rossz } & 51 & 49 & 100 \\
\hline & \multicolumn{3}{|c|}{ Imádkozom } \\
\hline & nem jellemzö & jellemző & összesen \\
\hline (nagyon) jó & 61 & 39 & 100 \\
\hline elfogadható & 45 & 55 & 100 \\
\hline \multirow[t]{3}{*}{ (nagyon) rossz } & 31 & 69 & 100 \\
\hline & \multicolumn{3}{|c|}{ Megtapasztaltam, hogy Isten része a személyes életemnel } \\
\hline & nem jellemző & jellemző & összesen \\
\hline (nagyon) jó & 69 & 31 & 100 \\
\hline elfogadható & 56 & 44 & 100 \\
\hline \multirow{3}{*}{ (nagyon) rossz } & 48 & 52 & 100 \\
\hline & \multicolumn{3}{|c|}{ Gyakran gondolkodom vallásos dolgokról } \\
\hline & nem jellemző & jellemző & összesen \\
\hline (nagyon) jó & 70 & 30 & 100 \\
\hline elfogadható & 51 & 49 & 100 \\
\hline (nagyon) rossz & 36 & 64 & 100 \\
\hline
\end{tabular}

6. táblázat. A vallásosság és a szubjektív egészségi állapot összefüggései (\%).

\section{Összegzés}

Számos elméleti konstrukció vonta be a vallásosságot és a spiritualitást az életminőséget leíró modellekbe - emellett empirikus vizsgálatok sora igazolta, hogy a hétköznapi élet horizontján túlmutató szellemi-lelki erőfeszítések, ahogyan a vallásosságot és a spiritualitást megragadhatjuk, értékes hozadékkal bírnak az egyén személyes jól-léte, egészsége, valamint társas kapcsolatai és önkifejezése szempontjából. Azon túl, hogy a vallásos részvétel során az egyén támogatást nyer a közösségtől, ahová tartozik, az elfogadás formális és informális aktusainak megélése kiegyensúlyozottabbá teszik az életét. A vallásosság közösségi eleme mellett hangsúlyosan 
jelenik meg az élet értelmét firtató, egzisztenciális kérdésekben, a vallás és spiritualitás eszközeivel jók kezelhetők a krízisek, és kiválóan biztosítható a személyes fejlődés. Emellett is meg kell azonban jegyezni, hogy általános jelenség a vallás és spiritualitás kiüresedése is, amely részben a formális részvételt torzítja a közösségi nyomásnak való behódolássá, részben az istenhit megélését szükíti le babonás tartalmakra - ezek egyike sem szolgál az egyén valódi támaszául.

A nyíregyházi életminőségvizsgálatok sorozatába az ötödik hullámban került be a vallásosság mérését szolgáló skála. Ennek adatai alapján megállapítható, hogy a lakosság negyedére jellemző a vallásos részvétel, egyúttal felére az imádkozás. Ez, és a többi, inkább személyes, mint közösség dimenzióban mért különbség alapján kijelenthető, hogy a lakosság kisebb részére jellemző az egyházias út követése, többek a maguk módján vallásosak - ennek a csoportnak pedig egy, a vizsgálat alapján meghatározhatatlan része inkább babonás, mintsem spirituális jelleggel. A nők, az idősebbek és a nehéz élethelyezett átéltek jellemzőbben gyakorolják valamely vallásos tevékenységet, vagy bírnak transzcendens tapasztalással. A vallásosság szoros összefüggést mutatott a szubjektív egészségi állapottal is, oly módon, hogy az egészségüket rosszabbnak érzékelők jellemezték magukat intenzívebb vallásossággal mind az öt szempont szerint.

\section{Felhasznált irodalom}

1. Barna Zs. (2007): A vallásosság és a szubjektív életminőség. In: Utasi Ágnes [szerk.] (2007): Az életminőség feltételei. Mühelytanulmányok. MTA Politikai Tudományok Intézete, Budapest. 116-134.

2. Bognár B (2008): Vallás és racionalitás a luhmanni perspektívában. Világosság 2008/9-10: 155-165.

3. Csíkszentmihályi, M. (1996): Creativity: Flow and the psychology of discovery and invention. New York: Harper Collins.

4. Durkheim, E. (2003): A vallási élet elemi formái. A totemisztikus rendszer Ausztráliában. Kultúrák keresztútján. L’Harmattan Kiadó, Budapest. [Az eredeti kiadás: Durkheim, E. (1925): Les Formes élémentaires de la vie religieuse. Le système totémisque en Australie. Alcan, Paris.]

5. Fábián G., Huszti É., Hüse L., Takács P. (2018): Életminőség Nyíregyházán. A nyíregyházi nagymintás társadalomkutatások első négy hulláma a megyeszékhelyen. Szabolcs-Szatmár-Beregi Szemle 53/3: 83-102.

6. Földvári M., Rosta G. (1998): A modern vallásosság megközelítési lehetőségei. Szociológiai szemle 1998/1: 127-137.

7. Frankl, V. (1996): Az ember az értelemre irányuló kérdéssel szemben. Kötet Kiadó, Budapest.

8. Glaeser, E. L., Sacerdote, B. I. (2002): Education and Religion. NBER Working Paper Number: 8080. National Bureau of Economic Research, Cambridge.

9. Huber, S., Huber, O. V. (2012): The Centrality of Religiosity Scale (CRS). Religions 2012/3.: 710-724 
10. Huszti É., Hüse L., Takács P., Fábián G., (2018): A „Nyíregyháza Életminősége 2018" vizsgálat és a kutatás módszertana. Acta Medicinae et Sociologica Vol.9. No.27. xx-Xx

11. Kopp M., (2003): A mentális és magatartási betegségek és zavarok gyakorisága és az általuk okozott társadalmi teher. In: Ádány R. (szerk.): A magyar lakosság egészségi állapota az ezredfordulón. Medicina, MTA Orvosi Osztály, Budapest, 191-206

12. Kopp M., Skrabski Á. (2003): Lelki egészség. In: Csaba György (szerk.): Egészségmegőrzés. Természet Világa 2003/II. 37-40.

13. Kopp M., Székely A., Skrabski Á. (2004): Vallásosság és egészség az átalakuló társadalomban. Mentálhigiéné és Pszichoszomatika 5/2: 103-125.

14. Livingston, K. (2002): Faith, Reason, and the Good Life. https://atlassociety.org/objectivism/atlas-university/deeper-dive-blog/3706faith-reason-and-the-good-life

15. Miller, W.R., \& Thoresen, C.E. (2003). Spirituality, religion, and health. An emerging field. American Psychologist, 58, 24-35.

16. Pikó, B. (2005). Lelki egészség a modern társadalomban. Budapest: Akadémiai Kiadó.

17. Pikó, B., Kovács, E., Kriston P. (2011): Spiritualitás - vallás - egészség. Fiatalok mentális egészsége a spirituális jóllét mutatóinak tükrében. Mentálhigiéné és Pszichoszomatika 12 (2011) 3, 261-276. DOI: 10.1556/Mental.12.2011.3.4

18. Rózsa S., Réthelyi J., Stauder A., Susánszky É., Mészáros E., Skrabski Á., Kopp M. (2003): A Hungarostudy 2002 országos reprezentatív felmérés általános módszertana és a felhasznált tesztbattéria pszichometriai jellemzői. Psychiatria Hungarica 18 (2): 83-94

19. Skrabski Á., Kopp M., Rózsa S., Réthelyi J. (2004): A koherencia mint a lelki és testi egészség alapvető meghatározója a mai magyar társadalomban. Mentálhigiéné és Pszichoszomatika 5 (1): 7-25.

20. Steen, T.A., Kachorek, L.V., \& Peterson, C. (2003). Character strengths among youth. Journal of Youth and Adolescence, 32, 5-16.

21. Takács P., Fábián G. (2018): Lokális Életminőség Index, Nyíregyháza 2018 valamint a multihalmaz alapú vizsgálatok lehetőségei. Acta Medicinae et Sociologica Vol 9. No. 27. 70-95.

22. Tokaji K.-né, Faragó M., Boros J. (2011): Objektíven szubjektív. Statisztikai Szemle 7-8: 786-790.

23. Tomka M. (1996): Vallás és vallásosság. Társadalmi Riport 1996. Tárki, Budapest. 592-61 